\title{
ROBUSTNESS OF GERMINATION ANALYSIS METHODS FOR Copaifera langsdorffii Desf. (Fabaceae) SEEDS
}

\author{
ROBUSTEZ DE MÉTODOS PARA ANÁLISE DA GERMINAÇÃO DE SEMENTES DE \\ Copaifera langsdorffii Desf. (Fabaceae)
}

\section{Denise Garcia de SANTANA ${ }^{1}$; Gabriela Alves LOBO$^{2}$; Antonieta Nassif SALOMÃOª Vanderley José PEREIRA ${ }^{4}$}

1. Professora Doutora, Universidade Federal de Uberlândia - UFU, Uberlândia, MG, Brazil. dgsantana @ umuarama.ufu.br; 2. Ms., Universidade Federal de Uberlândia - UFU, Uberlândia, MG, Brazil; 3. Researcher, Empresa Brasileira de Pesquisa Agropecuária Recursos Genéticos e Biotecnologia- EMBRAPA, Brasília, DF, Brazil; 4. Ms., Universidade Federal de Uberlândia - UFU, Uberlândia, MG, Brazil.

\begin{abstract}
Germination of Copaifera langsdorffii Desf. seeds is non-uniform and asynchronous and there is still no consensus on the factors affecting it. Thus, the goal was to measure the robustness of pre-germination methods used to determine germination rates of $C$. langsdorffii seeds of different levels of quality and to present criteria for seedling classification that culminate in the officialization of one of these methods. Pre-germination methods were tested and the scarification of seeds sterilized with $0.05 \% \mathrm{NaClO}$ was the most efficient for maximizing germination potential. Seeds of different quality were then treated with this method and collaborative tests evaluated by Ministry of Agriculture laboratories. These evaluations were based on normal seedlings produced from each seed lot. Morphofunctional classification was used throughout to determine essential seedling structures. Robustness of the method was measured by variance and the coefficient of variation of repeatability and reproducibility. Scarification and sterilization with sodium hypochlorite made it possible to both estimate the germination potential of seeds of different quality levels and reduce seedling infection and seed mortality. To analyze germination based on seedling criteria, normal seedlings of this species were defined as having thick cotyledons that are detached from the seed coat, developed hypocotyls and epicotyls and primary roots. These seedlings have woody primary roots and thick, sometimes poorly developed hypocotyls. Even though C. langsdorffii is a forest species and subject to high variability, the proximity of the percentages of normal seedlings among repetitions (low repeatability) and low inter-laboratory reproducibility reflecting the uniformity generated by the method.
\end{abstract}

KEYWORDS: Dormancy. Repeatability. Reproducibility. Seedling classification. Validation.

\section{INTRODUCTION}

The factors affecting germination of Copaifera langsdorffii Desf. seeds remain controversial after more than 30 years of research (BORGES; BORGES, 1979; NOLETO et al., 2010). Some authors have shown that immersion in sulfuric acid (BEZERRA et al., 2002; GUERRA et al., 2006b) or pre-soaking in water for $24,48,72$ or 96 $\mathrm{h}$ (DUARTE, 1979; BORGES et al., 1982; PEREZ; PRADO, 1993) promote germination. According to Noleto et al. (2010), similar germination rates between a control and seeds treated to overcome dormancy (scarified seeds) demonstrate that dormancy does not exist even though, according to the authors, imbibition was favored by soaking the seeds in sodium hypochlorite.

Uncertainty in the literature about whether seed dormancy exists is not restricted to $C$. langsdorffii. Because dormancy is a characteristic of the seed and not the species (FINCH-SAVAGE; LEUBNER-METZGER，2006;
THOMPSON; OOI, 2010), it is expected that some seeds of the same sample or lot will germinate whereas others will not. This ratio of germinated to ungerminated seeds within the same sample is common and probably greater for this species than for others. Records show germination rates of $71 \%$ (BEZERRA et al., 2002) and 83\% (NOLETO et al., 2010) without pre-treatment. Despite divergence on whether dormancy exists and what form it takes, the fact remains that $C$. langsdorffii germination rates are non-uniform, asynchronous and highly uncertain - i.e. there is low probability that seeds will germinate within the same time interval (PEREIRA et al., 2009).

The species has other characteristics that influence this divergence such as phenotypic plasticity (PINTO et al., 2004; COSTA et al., 2012), wide distribution throughout Brazil and greater genetic diversity compared to other tropical species (PINTO et al., 2004; CARVALHO et al., 2010). Although divergence may seem to be an obstacle to officializing a method of analyzing $C$. langsdorffii seed germination, it is not. This method must be 
capable of predicting the maximum capacity of normal seedling formation for lots or samples with distinct germination capacities (WAENY, 1980) and promote emergence uniformity regardless of the presence, type or degree of dormancy. This quality refers to method robustness, which can be quantified by repeatability and reproducibility measurements (WAENY, 1980; INTERNATIONAL SEED TESTING ASSOCIATION, 2007).

Studies on validating methods of germination analysis for Brazilian forest species are recent and inspired by a growing demand for seeds. One method of analyzing $C$. langsdorffii seed germination was validated and published in the Normative Instruction $n^{\text {o. }} 26$, September $10^{\text {th }}, 2012$ from the Ministry of Agriculture, D.O.U., 11/09/2012 - Section 1 (BRASIL, 2012). Thus, the goal of this work was to measure the robustness of pre-germination methods used to determine germination rates of $C$. langsdorffii seeds of different levels of quality and to present criteria for seedling classification that culminate in the officialization of one of these methods.

\section{MATERIAL AND METHODS}

Copaifera langsdorffii Desf. is a native plant species with a broad geographical distribution in the Brazilian territory (Figure 1). Fruits and seeds were collected from 13 individuals located in the Atlantic Rain Forest and Brazilian Savannah of Minas Gerais and São Paulo states - Brazil - and prepared by drying, seed extraction (from fruit) and aril removal. The seeds were divided into three lots according to their germination potential (high, intermediate and low quality) and based on seed coat permeability and origin. Seed coat permeability was inferred from a graph of percent seed weight
SANTANA, D. G. et al.

increase versus soaking time. The seeds (samples of 25 seeds per lot) were first weighed individually to determine initial mass and then placed in germination boxes on two sheets of filter paper, soaked in distilled water and kept in a BOD germination chamber at $25^{\circ} \mathrm{C}$. Seeds were subsequently weighed at intervals of 1,2 , and $4 \mathrm{~h}$ (depending on imbibition rate) until the first germination (approximately $176 \mathrm{~h}$ after initiation of soaking).

An extensive literature review was conducted to determine the factors that lead to the highest germination rates and/or highest numbers of normal seedlings of $C$. langsdorffii. The germination experiment was completely randomized with four replications of 25 seeds in a $5 \times 3$ factorial design. The first factor represents the sample quality (high, intermediate and low quality) and the second factor, the seed pre-treatment methods.

The methods were: sterilization with sodium hypochlorite $0.05 \%$ for 5 minutes, mechanical scarification, soaking in distilled water for 24 and $48 \mathrm{~h}$ and a control. The seeds used as the control sample were washed for 5 minutes in a detergent solution $(0.5 \mathrm{~mL}$ per $100 \mathrm{~mL}$ distilled water). Mechanical scarification consisted of sanding the upper sides (relative to the hilum) of the seeds and sterilizing with $0.05 \%$ sodium hypochlorite solution for 5 minutes before and 3 minutes after scarification. Before soaking for 24 and $48 \mathrm{~h}$, the seeds were sterilized in the same way as the control. After soaking, these seeds were sterilized for 3 minutes in $0.05 \%$ sodium hypochlorite. The seeds washed with detergent solution or sterilized with sodium hypochlorite were rinsed in running water and remained in distilled water for 3 minutes before sowing. 


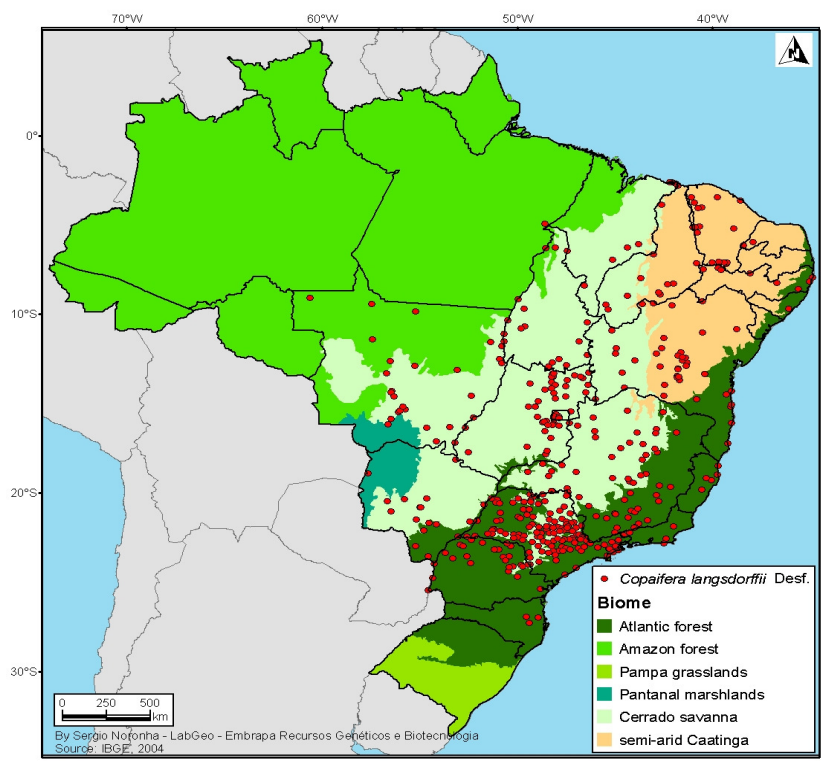

Figure 1. Copaifera langsdorffii Desf. geographical distribution in Brazil.

Seeds were alternately placed on two sheets of towel paper soaked in distilled water, covered with two more sheets and then rolled up. These rolls were then randomly selected, placed in plastic bags and incubated (BOD incubator) at $25^{\circ} \mathrm{C}$ under continuous white fluorescent light. The sheets were moistened with a solution of $0.5 \mathrm{~mL}$ of sodium hypochlorite ( 2 to $2.5 \% \mathrm{NaClO}$ ) per $2 \mathrm{~L}$ of distilled water. Assessments were made at 14, 21, 28 and 35 days after sowing by counting the number of seeds with primary root protrusion (germination), normal and abnormal (damaged and infected) seedlings, dead seeds and imbibed and unimbibed seeds (checked after 35 days). Seeds were determined to be imbibed or unimbibed based on a visual assessment of seed volume.

The morphofunctional seedling classification proposed by Ferraz and Calvi (2011) and the Manual of Seedling Development from the International Seed Testing Association (ISTA, 2006) were used to define the essential structures of seedlings and the modifications to these structures that would suggest abnormalities during the 35 days of evaluation. Infected abnormal seedlings were determined using the Rules for Seed Testing (BRASIL, 2009).

The Shapiro-Wilk test for normality of residuals and the Levene test of homogeneity of variances (both tests and all characteristics were tested at 0.01 significance level) were used to test the assumptions used in the analysis of variance model. When one or more of the assumptions were not met, the data were transformed by arcsine $\sqrt{x / 100}$, and then the assumptions were retested. The $F$ test (Snedecor) was run to determine principle effects and interactions. Means were compared by the Tukey test (0.05 significance level).

The seeds used in the seed germination experiment were sterilized with $0.05 \%$ sodium hypochlorite for 5 minutes, scarified by sanding the upper portion of the seeds and then sterilized again with $0.05 \%$ sodium hypochlorite for 3 minutes. This method was chosen to ensure that the germination rates were close to those found in the literature and to reduce seedling infection and seed mortality. In this process, three commercial seed lots of $C$. langsdorffii with distinct levels of quality were sent for testing at seven laboratories accredited by the Ministry of Agriculture. Details of the proposed method such as substrate type (paper germitest), container (gerbox), temperature $\left(25^{\circ} \mathrm{C}\right)$, lighting (continuous white fluorescent light), evaluation times (21, 28 and 35 days after sowing) and images of normal and abnormal seedlings were also sent to the laboratories.

The method was validated using only normal seedlings. Outliers were removed from the laboratory results by the Box-plot method (ISTA, 2007). Tests of the assumptions of normality of residuals and homogeneity of variances in the $3 \times 7$ factorial design (lots of different qualities and laboratories) and analysis of variance were the same as those used in the germination experiment. Robustness of the method was tested by calculating variances and coefficients of variation of repeatability and reproducibility for the model (AMERICAN SOCIETY FOR TESTING AND MATERIALS, 1992) and by lot (INTERNATIONAL ORGANIZATION FOR 
STANDARDIZATION, 1994). Additionally, the percentage of normal seedlings above critical levels was analyzed by lot and by laboratory using $k$ and $h$ statistics (MANDEL, 1991) at 0.01 significance.

\section{RESULTS}

Seeds from sample 1 (high quality seeds) increased in mass, had little resistance to water absorption and germinated at $176 \mathrm{~h}$ (at the conclusion of the readings) (Figure 2). Seeds from samples 2 and 3 (intermediate and low quality, respectively) also increased in mass, but not as much as seeds in sample 1, and had greater resistance to water absorption. Seed moisture was low and homogenous at $8.24,8.29$ and $9.92 \%$ for samples 1, 2 and 3, respectively.

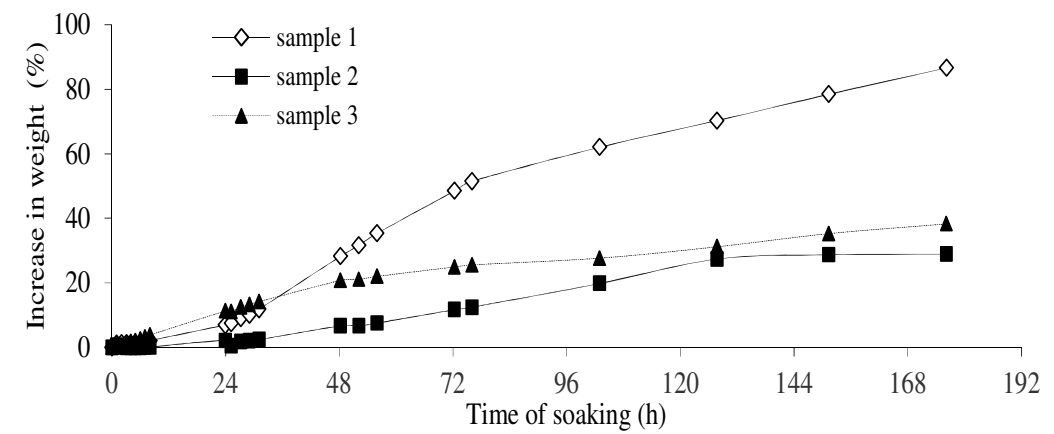

Figure 2. Percentage increase in weight of seeds Copaifera langsdorffii Desf. in function of time of soaking seeds in water at $25^{\circ} \mathrm{C}$.

Germination and normal seedling percentages showed that seed germination potential was distinctly different among the three samples (Table 1).

Seeds from sample 1, with low resistance to imbibition (Figure 2) had the highest percentages of germination and normal seedlings (95 and $88 \%$, respectively), without any pre-germination treatment. Sterilizing the seeds with $0.05 \%$ sodium hypochlorite did not improve germination or seedling development. However, scarification, preceded and followed by sterilization with $0.05 \%$ sodium hypochlorite, increased germination and normal seedling percentages in samples 2 and 3 (intermediate and low quality, respectively) and maintained these percentages in sample 1 (high quality).

In general, pre-soaking seeds for 24 or $48 \mathrm{~h}$ neither increased nor reduced germination and normal seedling percentages relative to the control regardless of seed germination potential (Table 1). However, germination did increase for intermediate quality seeds (sample 2) after soaking for $48 \mathrm{~h}$. The percentage of damaged abnormal seeds was less than $2 \%$ when seeds were scarified, but greater than $10 \%$ for all other methods including the control (Table 1). The highest percentage of damaged seedlings was found in the intermediate and low quality samples. The low percentage of infected abnormal seedlings (less than 6\%) and the similarity of these percentages between methods indicate that scarification and soaking did not cause contamination (Table 1).
At the end of the experiment, no imbibed seeds remained from those that had been scarified (Table 2). The maximum percentages of imbibed and hard seeds at the end of the experiment were 14 and $17 \%$, respectively (mainly seeds soaked for 24 and $48 \mathrm{~h}$ ). No imbibed seeds remained in the higher quality sample. The dead seed rate was $8.3 \%$ for untreated Copaifera langsdorffii seeds and scarification was the only treatment that reduced this percentage. The low-quality sample had the highest mortality rate (sample 3,16.8\%).

Morphofunctional criteria were established to classify normal seedlings. These criteria stipulate that normal $C$. langsdorffii seedlings must have developed hypocotyls (typical of epigeal seedlings) and storage cotyledons that are detached from the seed coat (Figure 3A). Therefore, these are classified as PER-seedlings (sensu FERRAZ; CALVI, 2011). In other words, these seedlings have developed epicotyls and primary roots that are essential for germination (sensu ISTA, 2006). Due to plasticity, other morphological variations or peculiarities were observed such as thickened hypocotyls and woody primary roots. Additionally, reduced hypocotyl development was observed when the seed coat detached immediately after radicle protrusion (Figure 3B).

Approximately $10 \%$ of the seedlings were damaged, which was mainly due to cracks and streaks in the hypocotyl and epicotyl (Figures 3C, D) and forking, folding (Figure 3E) and atrophy of the primary root. Although this percentage was low, infected seedlings had damage to more than $50 \%$ the cotyledon (Figure $3 \mathrm{~F}$ ), in the primary root 
and at the cotyledon insertion point (Figures 3G, H).

A combination of mechanical scarification and sterilization with $0.05 \%$ sodium hypochlorite before and after scarification was the most robust method for assessing the quality of $C$. langsdorffii seeds. Validation of this method revealed three outliers from the group of normal seedlings. One was from the intermediate quality lot (lot 2) and two from the low quality lot (lot 3, same laboratory) (Figure 4A). No outliers were found in the group of normal seedlings from the high quality. These three outliers were removed and no new outliers were encountered (Figure 4B).

Means seedling percentages in each lot were homogeneous and therefore the differences among laboratories were low and similar (6, 7 and $3 \%$ ) (Figure 5). Means percentages of normal seedlings $(93 \%, 70 \%$ and $61 \%$; respectively) reflected the adjectives used to describe each lot (high, intermediate and low quality, respectively) and demonstrated the capacity of these seeds to produce normal seedlings. Conformance with the assumptions of normality of residuals and homogeneity of variance $(P>0.01)$ allowed reliable inferences from the analysis of variance (Table 3 ). These inferences indicated that there were significant differences between lots $(P<0.01)$, but no significant differences for laboratories and interaction $(P>0.01)$. These results indicate, in the context of validation, that percentages of normal seedlings were distinct for the seed lots used and that mean percentages of normal seedlings from scarified $C$. langsdorffii seeds did not differ among the seven different laboratories, even for seed lots of different levels of quality. 
Table 1. Germination and seedling classification of seeds (Copaifera langsdorffii Desf. - Fabaceae) collected in 2011 from the Atlantic Forest and Savanna and treated with pre-germination methods.

\begin{tabular}{|c|c|c|c|c|c|c|c|c|}
\hline \multirow[b]{3}{*}{ Pre-germinative treatments ${ }^{1}$} & \multicolumn{4}{|c|}{ Germinability (\%) } & \multicolumn{4}{|c|}{ Normal seedlings $(\%)$} \\
\hline & \multicolumn{4}{|c|}{ Sample (quality) } & \multicolumn{4}{|c|}{ Sample (quality) } \\
\hline & 1-high & 2-intermediate & 3-low & & 1-high & 2-intermediate & 3-low & \\
\hline Control & $95.0 \mathrm{a} \mathrm{A}$ & 82.0 c B & $55.0 \mathrm{bc} \mathrm{C}$ & & $88.0 \mathrm{~b} \mathrm{~A}$ & $69.0 \mathrm{~b} \mathrm{~B}$ & $38.0 \mathrm{bc} \mathrm{C}$ & \\
\hline $0.05 \% \mathrm{NaClO}$ & $98.0 \mathrm{a} A$ & 78.0 c B & $69.0 \mathrm{~b} \mathrm{~B}$ & & $94.0 \mathrm{ab} \mathrm{A}$ & $58.0 \mathrm{~b} \mathrm{~B}$ & $55.0 \mathrm{~b} \mathrm{~B}$ & \\
\hline $0.05 \% \mathrm{NaClO}+$ scarification $+0.05 \% \mathrm{NaClO}$ & 99.0 a $\mathrm{AB}$ & $100.0 \mathrm{a} \mathrm{A}$ & 93.0 a B & & $96.0 \mathrm{ab} \mathrm{A}$ & 97.0 a $\mathrm{A}$ & 78.0 a B & \\
\hline Pre-soaking for $24 \mathrm{~h}+0.05 \% \mathrm{NaClO}$ & $100.0 \mathrm{a} \mathrm{A}$ & $87.0 \mathrm{bc} \mathrm{B}$ & 43.0 c C & & 98.0 a $\mathrm{A}$ & $63.0 \mathrm{~b} \mathrm{~B}$ & 26.0 c C & \\
\hline Pre-soaking for $48 \mathrm{~h}+0.05 \% \mathrm{NaClO}$ & $98.0 \mathrm{aA}$ & $95.0 \mathrm{ab} \mathrm{A}$ & $58.0 \mathrm{bc} \mathrm{B}$ & & $89.0 \mathrm{ab} \mathrm{A}$ & $77.0 \mathrm{~b} \mathrm{~A}$ & $38.0 \mathrm{bc} \mathrm{B}$ & \\
\hline \multicolumn{9}{|l|}{ Mean } \\
\hline 2Levene $(F) /$ Shapiro-Wilk $(W)$ & \multicolumn{4}{|c|}{$0.969 / 1.726$} & \multicolumn{4}{|c|}{$2.313 / 0.955$} \\
\hline \multirow[t]{3}{*}{ Data transformation } & \multicolumn{4}{|c|}{$\operatorname{arcoseno} \sqrt{x / 100}$} & \multicolumn{4}{|c|}{$\operatorname{arcoseno} \sqrt{x / 100}$} \\
\hline & \multicolumn{4}{|c|}{ Damaged seedlings $(\%)$} & \multicolumn{4}{|c|}{ Infected seedlings $(\%)$} \\
\hline & \multicolumn{4}{|c|}{ Sample (quality) } & \multicolumn{4}{|c|}{ Sample (quality) } \\
\hline Pre-germinative treatments ${ }^{1}$ & 1-high & 2-intermediate & 3-low & Mean & 1-high & 2-intermediate & 3-low & Mean \\
\hline Control & 5.0 & 13.0 & 13.0 & $10.3 \mathrm{~b}$ & 2.0 & 0.0 & 4.0 & $2.0 \mathrm{a}$ \\
\hline $0.05 \% \mathrm{NaClO}$ & 3.0 & 19.0 & 10.0 & $10.7 \mathrm{~b}$ & 1.0 & 1.0 & 4.0 & $2.0 \mathrm{a}$ \\
\hline $0.05 \% \mathrm{NaClO}+$ scarification $+0.05 \% \mathrm{NaClO}$ & 2.0 & 1.0 & 2.0 & $1.7 \mathrm{a}$ & 1.0 & 2.0 & 13.0 & $5.3 \mathrm{a}$ \\
\hline Pre-soaking $24 \mathrm{~h}+0.05 \% \mathrm{NaClO}$ & 2.0 & 20.0 & 14.0 & $12.0 \mathrm{~b}$ & 0.0 & 4.0 & 3.0 & $2.3 \mathrm{a}$ \\
\hline Pre-soaking $48 \mathrm{~h}+0.05 \% \mathrm{NaClO}$ & 5.0 & 15.0 & 14.0 & $11.3 \mathrm{~b}$ & 4.0 & 3.0 & 6.0 & $4.3 \mathrm{a}$ \\
\hline Mean & $3.4 \mathrm{~A}$ & $13.6 \mathrm{~B}$ & $10.6 \mathrm{~B}$ & & $1.6 \mathrm{~A}$ & $2.0 \mathrm{AB}$ & $6.0 \mathrm{~B}$ & \\
\hline${ }^{2}$ Levene $(F)$ /Shapiro-Wilk $(W)$ & \multicolumn{4}{|c|}{ 1.171/0.975 } & \multicolumn{4}{|c|}{$3.079 / 0.975$} \\
\hline Data transformation & \multicolumn{4}{|c|}{$\operatorname{arcoseno} \sqrt{x / 100}$} & \multicolumn{4}{|c|}{ arcoseno $\sqrt{x / 100}$} \\
\hline
\end{tabular}

${ }^{1}$ Means followed by the same letter, small in the column and capital letters in the line, are not significantly different based on the Tukey tests $(P>0.05) ;{ }^{2} F$ e $W$ : boldfaced values indicate residuals with normal distribution and homogeneous variances $(P>0.01)$, respectively. 
Table 2. Categorization of ungerminated seeds (Copaifera langsdorffii Desf. - Fabaceae) collected in 2011 from the Atlantic Forest and Savanna and treated with pre-germination methods.

\begin{tabular}{|c|c|c|c|c|}
\hline \multirow[b]{3}{*}{ Pre-germinative treatments ${ }^{1}$} & \multicolumn{3}{|c|}{ Sample (quality) } & \\
\hline & \multicolumn{3}{|c|}{ Fresh seeds $(\%)$} & \\
\hline & 1-high & 2-intermediate & 3-low & \\
\hline Control & $0.0 \mathrm{aA}$ & $4.0 \mathrm{ab} \mathrm{A}$ & $13.0 \mathrm{~b} \mathrm{~B}$ & \\
\hline $0.05 \% \mathrm{NaClO}$ & $0.0 \mathrm{a} \mathrm{A}$ & $10.0 \mathrm{~b} \mathrm{~B}$ & $11.0 \mathrm{~b} \mathrm{~B}$ & \\
\hline $0.05 \% \mathrm{NaClO}+$ scarification $+0.05 \% \mathrm{NaClO}$ & $0.0 \mathrm{a} \mathrm{A}$ & $0.0 \mathrm{a} \mathrm{A}$ & $0.0 \mathrm{a} \mathrm{A}$ & \\
\hline Pre-soaking $24 \mathrm{~h}+0.05 \% \mathrm{NaClO}$ & $0.0 \mathrm{a} \mathrm{A}$ & $4.0 \mathrm{ab} \mathrm{A}$ & $14.0 \mathrm{~b} \mathrm{~B}$ & \\
\hline Pre-soaking $48 \mathrm{~h}+0.05 \% \mathrm{NaClO}$ & $0.0 \mathrm{a} \mathrm{A}$ & $2.0 \mathrm{ab} \mathrm{A}$ & $14.0 \mathrm{~b} \mathrm{~B}$ & \\
\hline \multirow[t]{2}{*}{${ }^{2}$ Levene $(F) /$ Shapiro-Wilk $(W)$} & \multicolumn{3}{|c|}{$8.892 / 0.877$} & \\
\hline & \multicolumn{3}{|c|}{ Hard seeds $(\%)$} & \\
\hline Pre-germinative treatments ${ }^{1}$ & 1-high & 2-intermediate & 3-low & \\
\hline Control & $0.0 \mathrm{a} \mathrm{A}$ & $10.0 \mathrm{~b} \mathrm{~B}$ & $16.0 \mathrm{bc} \mathrm{B}$ & \\
\hline $0.05 \% \mathrm{NaClO}$ & $0.0 \mathrm{a} \mathrm{A}$ & $10.0 \mathrm{~b} \mathrm{~B}$ & $5.0 \mathrm{ab} \mathrm{AB}$ & \\
\hline $0.05 \% \mathrm{NaClO}+$ scarification $+0.05 \% \mathrm{NaClO}$ & $0.0 \mathrm{a} \mathrm{A}$ & $0.0 \mathrm{a} \mathrm{A}$ & $0.0 \mathrm{a} \mathrm{A}$ & \\
\hline Pre-soaking $24 \mathrm{~h}+0.05 \% \mathrm{NaClO}$ & $0.0 \mathrm{a} \mathrm{A}$ & $3.0 \mathrm{ab} \mathrm{A}$ & $17.0 \mathrm{c} \mathrm{B}$ & \\
\hline Pre-soaking $48 \mathrm{~h}+0.05 \% \mathrm{NaClO}$ & $0.0 \mathrm{a} \mathrm{A}$ & $2.0 \mathrm{ab} \mathrm{AB}$ & $8.0 \mathrm{ab} \mathrm{B}$ & \\
\hline \multirow[t]{2}{*}{ '2Levene $(F) /$ Shapiro-Wilk $(W)$} & \multicolumn{3}{|c|}{$4.596 / 0.833$} & \\
\hline & \multicolumn{3}{|c|}{${ }^{3}$ Dead seeds $(\%)$} & \\
\hline Pre-germinative treatments ${ }^{1}$ & 1-high & 2-intermediate & 3-low & Mean \\
\hline Control & 5.0 & 4.0 & 16.0 & $8.3 \mathrm{~b}$ \\
\hline $0.05 \% \mathrm{NaClO}$ & 2.0 & 2.0 & 15.0 & $6.3 \mathrm{ab}$ \\
\hline $0.05 \% \mathrm{NaClO}+$ scarification $+0.05 \% \mathrm{NaClO}$ & 1.0 & 0.0 & 7.0 & $2.7 \mathrm{a}$ \\
\hline Pre-soaking $24 \mathrm{~h}+0.05 \% \mathrm{NaClO}$ & 0.0 & 6.0 & 26.0 & $10.7 \mathrm{~b}$ \\
\hline Pre-soaking $48 \mathrm{~h}+0.05 \% \mathrm{NaClO}$ & 2.0 & 1.0 & 20.0 & $7.7 \mathrm{ab}$ \\
\hline Mean & $2.0 \mathrm{~A}$ & $2.6 \mathrm{~A}$ & $16.8 \mathrm{~B}$ & \\
\hline${ }^{2}$ Levene $(F)$ /Shapiro-Wilk $(W)$ & & $2.824 / 0.970$ & & \\
\hline
\end{tabular}

${ }^{1}$ Means followed by the same letter, small in the column and capital letters in the line, are not significantly different based on the Tukey tests $(P>0.05) ;{ }^{2} \mathrm{~F}$ e $W$ : boldfaced values indicate residuals with normal distribution and homogeneous variances $(P>0.01)$, respectively; ${ }^{3}$ Data transformation arcoseno $\sqrt{x / 100}$
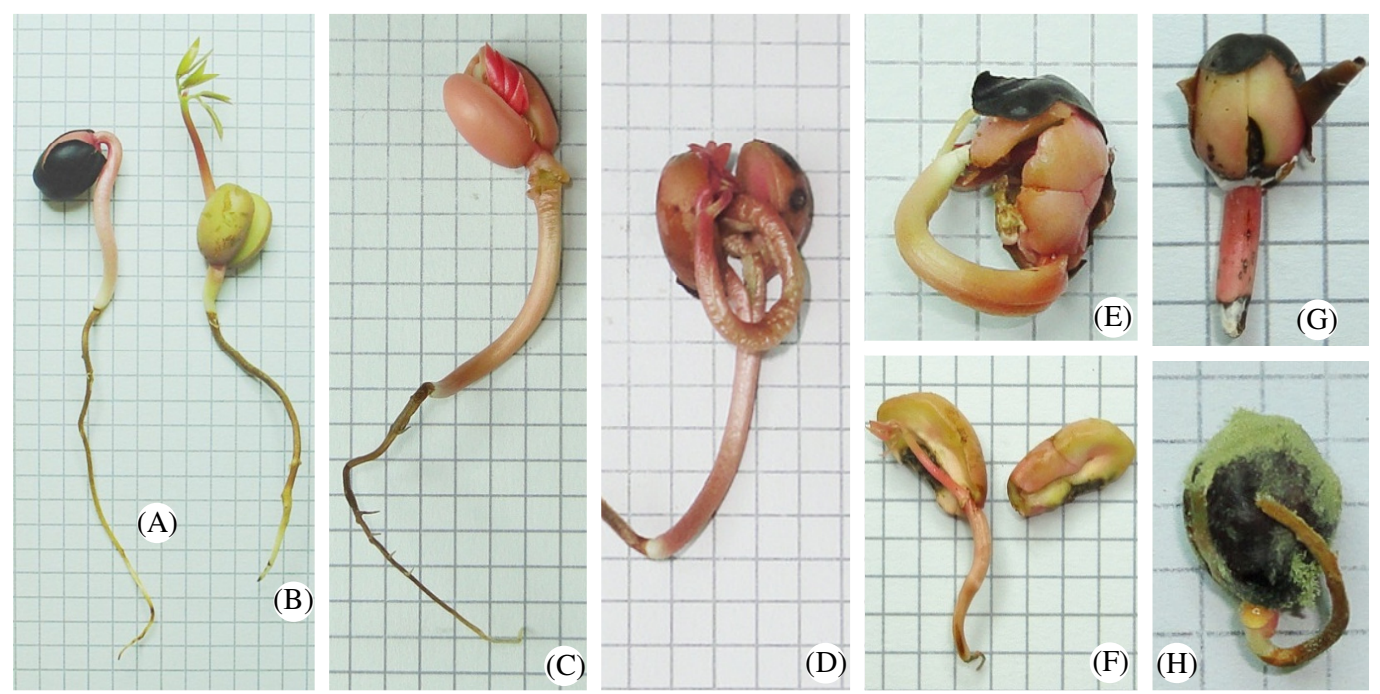

Figure 3. Seedlings of Copaifera langsdorffii Desf. Normal seedlings: A: exposed cotyledons, hypocotyl developed; B: free cotyledons, hypocotyl undeveloped, developed epicotyl, A, B: subwood primary root. Damaged seedlings: C, D: hypocotyl cracked with conductive tissue damaged; D: epicotyl spiral and rough; E: damaged cotyledons and bifurcated and curled primary root; F: stunted primary root. Infected seedlings: F: infected primary root; G: primary root and the insertion area of the cotyledons infected and $\mathrm{H}$ : primary infection, cotyledons with over $50 \%$ of the infected area. Scale $=1 \mathrm{~cm}$. 

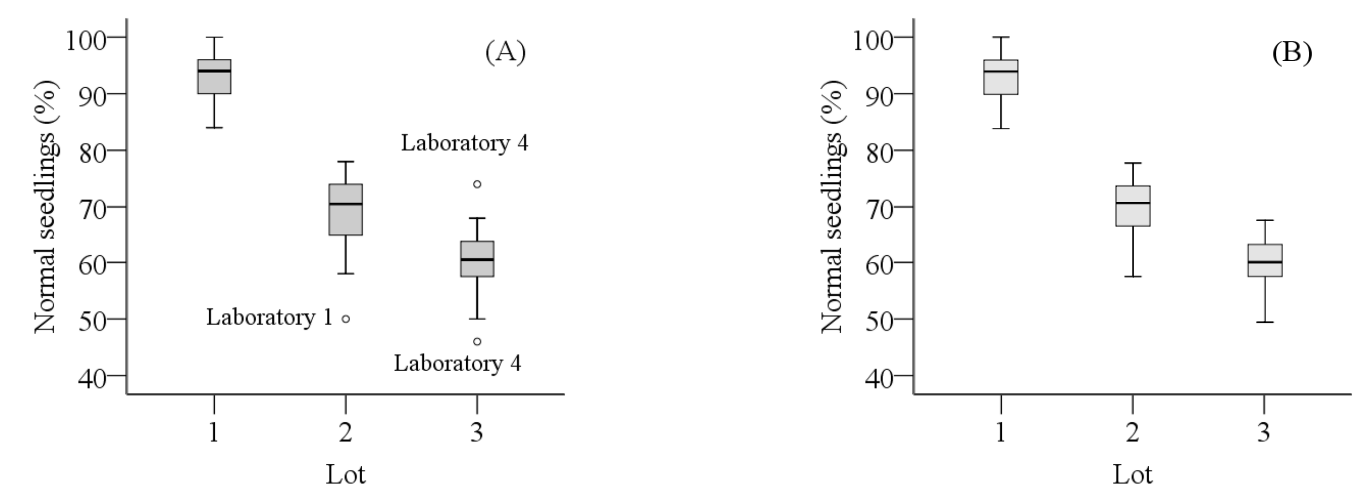

Figure 4. Box plot by lot with (A) and without outliers (B) of normal Copaifera langsdorffii Desf. - Fabaceae seedlings percentages obtained from the germination analysis of seeds scarified for the validation process.

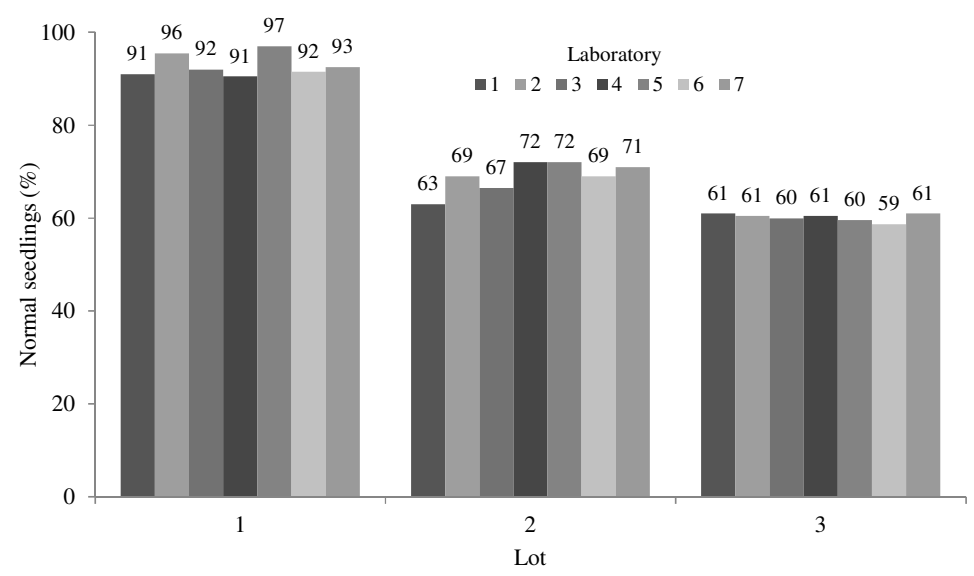

Figure 5. Means percentages of normal Copaifera langsdorffii Desf. - Fabaceae seedlings obtained by lot and by laboratory from the germination analysis of seeds scarified for the validation process.

Table 3. Analysis of variance for the percentages of normal seedlings in the batch vs. laboratory factorial model for the validation of Copaifera langsdorffii Desf - Fabaceae seeds.

\begin{tabular}{|c|c|c|c|c|c|c|c|c|c|c|c|}
\hline \multirow{2}{*}{$\begin{array}{l}\text { Sources of } \\
\text { variation }^{1}\end{array}$} & \multicolumn{3}{|c|}{ ANAVA } & \multicolumn{2}{|c|}{ Model $^{2}$} & \multicolumn{2}{|c|}{ Lot 1} & \multicolumn{2}{|c|}{ Lot 2} & \multicolumn{2}{|c|}{ Lot 3} \\
\hline & $g l$ & $Q M$ & $P$ & $s_{r}^{2}$ & $C V_{r}$ & $s_{r}^{2}$ & $C V_{r}$ & $s_{r}^{2}$ & $C V_{r}$ & $s_{r}^{2}$ & $C V_{r}$ \\
\hline Lot & 2 & 7431.8 & 0.000 & 24.6 & 6.7 & 15.7 & 4.3 & 32.0 & 8.1 & 21.0 & 7.6 \\
\hline Laboratory & 6 & 23.8 & 0.455 & $s_{R}^{2}$ & $C V_{R}$ & $s_{R}^{2}$ & $C V_{R}$ & $s_{R}^{2}$ & $C V_{R}$ & $s_{R}^{2}$ & $C V_{R}$ \\
\hline Lot*Laboratory & 12 & 13.8 & 0.863 & 0 & 0 & 17.1 & 4.4 & 30.7 & 7.9 & 16.5 & 6.7 \\
\hline
\end{tabular}

Assumptions $^{2} \quad W=\mathbf{0 . 9 8 1} / F=\mathbf{1 . 6 4 4}$

${ }^{1}$ gl: degrees of freedom; $Q M$ : mean square; $P$ : probability; ${ }^{2} W ; F$ : statistics of Shapiro-Wilk and Levene's tests; respectively; boldfaced values indicate residuals with normal distribution and homogeneous variances; ${ }^{2} s_{r}^{2}$ : variance of repeatability; $s_{R}^{2}$ : variance of reproducibility; $C V_{r}$ : coefficient of variation of repeatability and $C V_{R}$ : coefficient of variation of reproducibility.

The variances and coefficients of variation were greater for model repeatability than for model reproducibility, which demonstrate that differences in the percentages of normal plants were greater between repetitions than between laboratories (Table 3). 
However, lot variability (variance and the coefficient of variation) was similar between repetitions and laboratories. No differences in normal seedlings between replicates, above a maximum limit, were found at any of the laboratories (Figure 6A). Additionally, no outliers were found when comparing the average number of normal seedlings between laboratories (Figure 6B).

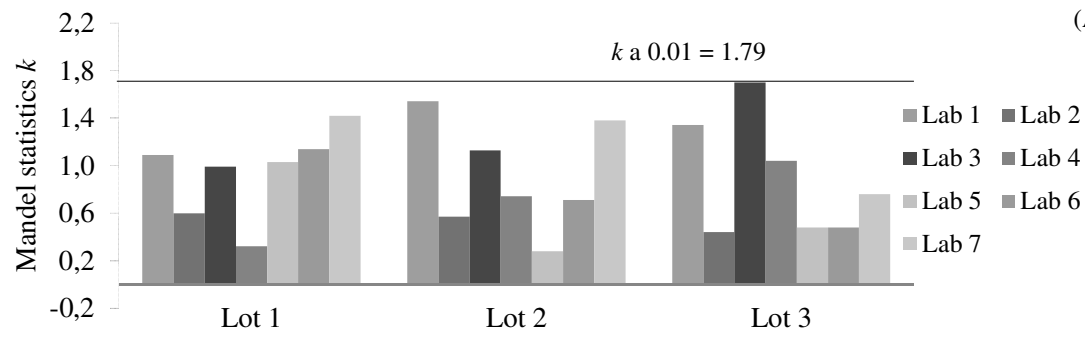

$$
2,4
$$

$h$ at $0.01=1.98$

(B)

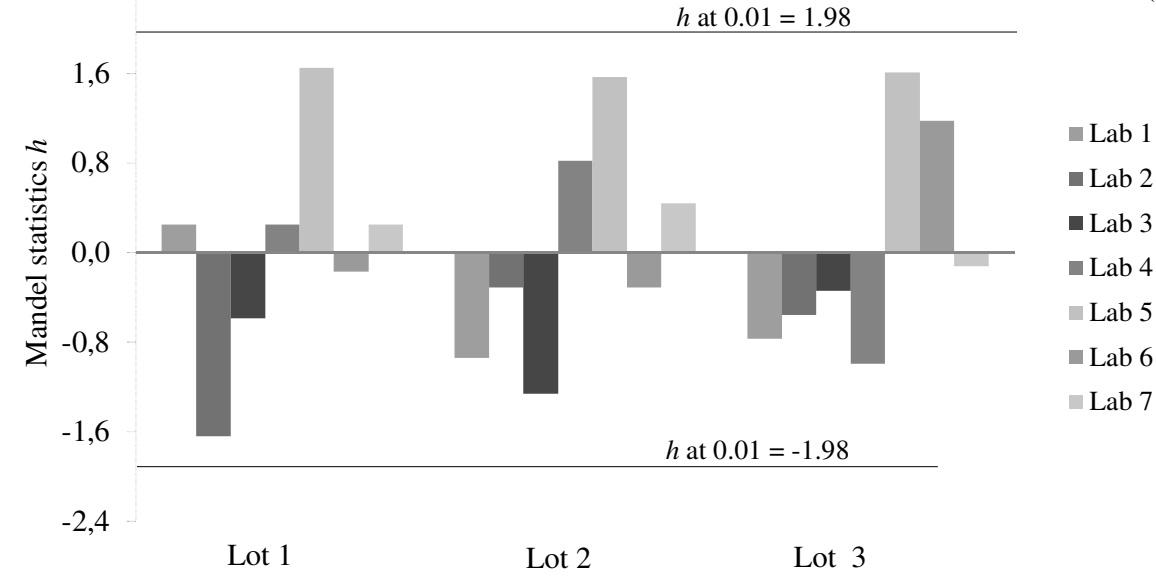

Figure 6. Mandel statistics $(k$ and $h)$ that identify laboratories with percentages of normal seedling between repetitions that are above critical limits, statistic $k(\mathrm{~A})$, or mean that are outliers relative to other laboratories, statistic $h(\mathrm{~B})$.

\section{DISCUSSION}

Chemical composition, ethnobotanical aspects and medicinal properties of the oil-resin produced by species of the Copaifera genus are recurring themes in the literature (RIGAMONTE-AZEVEDO et al., 2006; VEIGA JÚNIOR et al., 2007). In contrast, fruit, seed and seedling morphology of Copaifera langsdorffii Desf. are less frequent themes and seed germination is still controversial. One controversy stems from the quality of the sample used to make inferences about factors affecting germination. Another controversy arises from using seed coat morphology (permeable and non-permeable) as the only determinant of imbibition capacity.

High germination rates $(>80 \%)$ found in several studies (BORGES; BORGES, 1979; BORGES et al., 1982; NOLETO et al., 2010) for seeds without any pre-germination treatment and for seeds pre-sterilized with sodium hypochlorite indicate that the seed coat of $C$. langsdorffii seeds does not restrict imbibition in some samples. Nevertheless, this observation cannot be generalized. Seeds from one of the samples in the current study registered low germination potential (55\%), which was $16 \%$ lower because of seeds that did not imbibed water.

An analysis of the seeds from the three samples with distinct imbibition capacities (as confirmed by the permeability curve) shows that treatment with $0.05 \%$ sodium hypochlorite alone did not increase germination rates and did not differ from the control. However, combining this treatment with scarification increased germination, decreased seed mortality and did not leave any unimbibed seeds at the end of the experiment. Some reports show that either scarification or sodium hypochlorite alone allows seeds to imbibed water faster because of damage to the seed coat or partial removal of the cuticle by $\mathrm{NaClO}$ (NOLETO et al., 2010). Perhaps for the same reason, satisfactory results were achieved by immersion in sulfuric acid (BEZERRA et al., 2002; GUERRA et al., 2006b) or soaking in water for different times (BORGES et al., 1982). The impact of sodium hypochlorite scarification (HSIAO et al., 1981; CARNELOSSI et al., 1995; FERREIRA; RANAL, 1999) on the 
cuticle of $C$. langsdorffii seeds may have led to the high germination percentages found by Bezerra et al. (2002) and Noleto et al. (2010).

The cuticle is not the only barrier to germination and normal seedling formation. The seed testa restricts root emergence (FINCHSAVAGE; METZGER-LEUBNER, 2006). Superficial scarification of the seed coat allowed both the primary root and, more significantly, the cotyledons to emerge, which reduced the percentage of abnormal damaged seedlings. A slightly undeveloped hypocotyl was not considered an abnormality in this study and was instead classified as a morphological variation, even though this species is typically epigeal (RESSEL et al., 2004; GUERRA et al., 2006a).

Literature specific to seedling evaluation (ISTA, 2006; BRASIL, 2009) normally considers that fungi are the cause of darkened, pigmented and especially softened seedling tissue. Nevertheless, the browning in the primary roots of this species' seedlings is due to the woody character of the root and not to infection. The same has been observed in other species of Fabaceae (FÉLIX-DA-SILVA et al., 2009; NOGUEIRA et al., 2010; SOUSA et al., 2010).

The germination data showed that $C$. langsdorffii seed scarification and the action of sodium hypochlorite was not only efficient but also robust. Measuring repeatability and reproducibility in scientific research and particularly in seed germination analysis allows quantification of the stability and robustness of a method given variations in environment, genetics, procedure and implementation (CARAGUEL et al., 2009). The greater variance and coefficients of variation of repeatability found for low and intermediate quality seed lots underscore the difficulty of analyzing the germination of $C$. langsdorffii seeds as their quality decreases. However, this condition is not peculiar to this species. Germination tests of Vicia faba L. showed lower standard deviations of repeatability for seeds with higher percentages of normal seedlings (DUCOURNAU et al., 2009).

Reproducibility variances were higher than repeatability variances for normal $C$. langsdorffii seedlings. Even in species that are more stable and less subject to genetic and environmental variability such as crops, variation is still greater between analyses than between repetitions in germination tests. Examples of this include Helianthus annus L. (DUCOURNAU et al., 2008), Pisum sativum L. (FIELDER et al., 2008), $V$. faba (DUCOURNAU et al., 2009), Raphanus sativus L. var. oleiferus L. Sazonova \& Stank (KATAOKA et al., 2011) and Zea mays L. (MATTHEWS et al., 2011). Although there are no standards for repeatability and reproducibility (POWELL, 2009), especially for forest species, coefficients of variation below $10 \%$ demonstrate the stability of the methods used in this study to determine the potential of normal $C$. langsdorffii seedlings.

Research on the germination of seeds with distinct germination potentials combined with an investigation of the robustness of seed scarification methods (pre-sterilized and post-sterilized with sodium hypochlorite) led to the officialization of this procedure by the Ministry of Agriculture (BRASIL, 2012). The goal of officialization is to promote a low-risk germination test method for $C$. langsdorffii seeds, without limiting research on the officialization of new methods.

\section{ACKNOWLEDGEMENTS}

The authors would like to recognize The National Council for Scientific and Technological Development (CNPq) and the Research Support Foundation of the State of Minas Gerais (FAPEMIG) for financial support and the scholarship granted to the second author.

RESUMO: A germinação de sementes de Copaifera langsdorffii Desf. - Fabaceae é descrita na literatura como desuniforme, assíncrona e com alto grau de incerteza, permanecendo controversos os fatores que a afetam. Diante disso, os objetivos foram determinar, por princípios metrológicos, a robustez de métodos pré-germinativos para as sementes da espécie com qualidades distintas e apresentar os critérios para a classificação das plântulas que culminaram com a oficialização de um dos métodos. Na primeira etapa, métodos pré-germinativos literatura foram testados e a escarificação das sementes desinfestadas com $\mathrm{NaClO}$ a $0,05 \%$ foi o mais eficiente para determinar o potencial de germinação das sementes. Na segunda etapa, esse método aplicado a lotes com qualidades distintas foi submetido a avaliação colaborativa entre laboratórios credenciados pelo Ministério da Agricultura, Pecuária e Abastecimento e avaliado com base nos percentuais de plântulas normais. Nas duas etapas, a classificação morfofuncional determinou as estruturas essenciais das plântulas da espécie no decorrer da análise de germinação. A robustez do método foi medida pela variância e coeficiente de variação de repetitividade e reprodutibilidade. A escarificação e desinfestação das sementes com hipoclorito de sódio permitem estimar o potencial de germinação das sementes de Copaifera langsdorffii com qualidades distintas, reduzindo a infecção das plântulas e a mortalidade das sementes. Na análise da germinação baseada no critério de plântulas, as 
plântulas normais da espécie devem apresentar cotilédones espessos e liberados do tegumento, hipocótilo e epicótilo desenvolvidos, além de raiz primária. São particularidades das plântulas da espécie, a raiz primária sublenhosa e o hipocótilo espesso, e pouco desenvolvido. Mesmo sendo Copaifera langsdorffii uma espécie florestal e sujeita à alta variabilidade, a proximidade dos percentuais de plântulas normais entre repetições, baixa repetitividade, e entre laboratórios, baixa reprodutibilidade, refletem a uniformidade gerada pelo método.

PALAVRAS-CHAVE: Classificação de plântulas. Dormência. Repetitividade. Reprodutibilidade. Validação.

\section{REFERENCES}

AMERICAN SOCIETY FOR TESTING AND MATERIALS. ASTM E691/92. Standard practice for conducting an interlaboratory study to determine the precision of a test method. Philadelphia: American Society for Testing and Materials, 1992. 20p.

BEZERRA, A. M. E.; MEDEIROS FILHO, S.; MOREIRA, M. G.; MOREIRA, F. J. C.; ALVES, T. T. L. Germination and development of copaiba seedlings as a function of the size and immersion of the seed in sulfuric acid. Revista Ciência Agronômica, Fortaleza, v. 33, n. 2, p. 79-84, 2002.

BORGES, E. E. L.; BORGES, R. C. G. Copaifera langsdorffii seed germination from fruits with different degrees of maturation. Revista Brasileira de Sementes, Londrina, v. 1, n. 3, p. 45-47, 1979.

http://dx.doi.org/10.17801/0101-3122/rbs.v4n1p9-12

BORGES, E. E. L.; BORGES, R. C. G.; CANDIDO, J. F.; GOMES, J. M. Comparison of dormancy breaking methods in copaiba (Copaifera langsdorffii) seeds. Revista Brasileira de Sementes, Londrina,v. 4, n. 1, p. 9$12,1982$.

BRASIL. Instrução Normativa ${ }^{\circ}$ 26, de 10 de Setembro de 2012. Diário oficial da União. Poder executivo, Brasília, DF, 11 set. 2012. Seção I, p.5. Disponível em:<

http://pesquisa.in.gov.br/imprensa/jsp/visualiza/index.jsp?data=11/09/2012\&jornal=1\&pagina=5\&totalArquivo $\mathrm{s}=156>$. Acesso em 13 dez. 2014.

BRASIL. Regras para análise de sementes. 1. ed. Brasília: Ministério da Agricultura, Pecuária e Abastecimento, 2009. 395 p.

CARAGUEL, C.; STRYHN, H.; GAGNÉ, N.; DOHOO, I.; HAMMELL, L. Traditional descriptive analysis and novel visual representation of diagnostic repeatability and reproducibility: Application to an infectious salmon anaemia virus RT-PCR assay. Preventive Veterinary Medicine. v. 92, n. 1-2, p. 9-19. 2009. http://dx.doi.org/10.1016/j.prevetmed.2009.07.011

CARNELOSSI, M. A. G.; LAMOUNIER, L.; RANAL, M. A. Effect of light, sodium hypochlorite, scarification, and stratification on seed germination of lettuce (Lactuca sativa L.) cv. "maioba" and "moreninha-de-uberlândia”. Pesquisa Agropecuária Brasileira, Brasília, v. 30, n. 6, p. 779-787, 1995.

CARVALHO, A. C. M.; FREITAS, M. L. M.; MORAES, S. M. B.; MORAES, M. L. T.; STRANGHETTI, V.; ALZATE-MARIN, A. L.; SEBBENN, A. M. Genetic diversity, inbreeding and gene flow in a small fragmented population of Copaifera langsdorffii. Revista Brasileira de Botânica, São Paulo, v. 33, n. 4, p. 599-606, 2010.

COSTA, M. C.; PEREIRA, J. A. A.; BENICIO, M. H. M.; SOUSA, H.; FONTES, M. A. L.; GARCIA, P. O. Allometry and architecture of Copaifera langsdorffii (Desf.) Kuntze (Fabaceae) in neotropical physiognomies in southeastern Brazil. Ciência Florestal, Santa Maria, v. 22, n. 2, p. 223-240, 2012.

DUARTE, A. P. Contribution to the knowledge of seed germination of the most common essences.

Rodriguésia, Rio de Janeiro, v.31, n. 48, p. 59-68, 1979. 
DUCOURNAU, S.; GARREAU, P.; LÉCHAPPÉ, J. Effect of temperature and growing media on sunflower germination. Basserdorf: ISTA Method Validation Reports, n.135, p.34-36, 2008.

DUCOURNAU, S.; GARREAU, P.; MALLET, L.; LÉCHAPPÉ, J. Use of organic growing media as primary substrate for the germination of Vicia faba L. seeds. ISTA Method Validation Reports. Basserdorf: International Seed Testing Association, n. 6, p. 58-63, 2009.

FÉLIX-DA-SILVA, M. M.; BASTOS, M. N. C.; GURGEL, E. S. C. Taxonomic and morphological aspects of the germination and seedling of Peltogyne venosa subsp. densiflora (Spruce ex Benth.) M. F. Silva

(Leguminosae - Caesalpinioideae). Boletim do Museu Paraense Emílio Goeldi, Belém, v. 4, n. 3, p. 291-302, 2009.

FERRAZ, I. D. K.; CALVI, G. P. Teste de germinação. p.1-36. In: LIMA JÚNIOR, M. J. V. (ed.). Manual de procedimentos para análise de sementes florestais. Londrina: Associação Brasileira de Tecnologia de Sementes. 2011. p. 55-122;

FERREIRA, W. R.; RANAL, M. A. Seed germination and seedling growth of Brassica chinensis L. var. parachinensis (BAILEY) Sinskaja (flowering white cabbage). Pesquisa Agropecuária Brasileira, Brasília, v. 34, n. 3, p. 353-361, 1999. http://dx.doi.org/10.1590/S0100-204X1999000300005

FIELDER, K. A.; GUTORMSON, T. J.; BRIX-DAVIS, K. A.; CARLSON, L. N. Evaluation of crepe cellulose paper (Versa-Pak ${ }^{\circledR}$ ) covered with sand as an ISTA medium. ISTA Method Validation Reports. Basserdorf: International Seed Testing Association, n.6, p.9-32, 2008.

FINCH-SAVAGE, W. E.; LEUBNER-METZGER, G. Seed dormancy and the control of germination. New Phytologist, Lancaster, v. 171, n. 3, p. 501-523, 2006. http://dx.doi.org/10.1111/j.1469-8137.2006.01787.x

GUERRA, M. E. C.; MEDEIROS FILHO, S.; GALLÃO, M. I. Seed, seedlings and germination morphology of Copaifera langsdorffii Desf. (Leguminosae-Caesalpinioideae). Cerne, Lavras, v. 12, n. 4, p. 322-328, $2006 a$.

GUERRA, M. E. C.; MEDEIROS FILHO, S.; TEÓFILO, E. M. Effect of temperature and light on Copaifera langsdorfii Desf. seed germination. Revista Caatinga, Mossoró, v. 19, n. 1, p. 39-43, $2006 \mathrm{~b}$.

HSIAO, A. I.; WORSHAM, A. D.; MORELAND, D. E. Effects of sodium hypochlorite and certain plant growth regulators on germination of witch weed (Striga asiatica) seeds. Weed Science, Lawrence, v. 29, n.1, p. 98-100, 1981.

INTERNATIONAL ORGANIZATION FOR STANDARDIZATION. Accuracy (trueness and precision) of measurement methods and results - Part 2: basic method for determination of repeatability and reproducibility of a standard measurement method. 1. ed. Geneva: International Organization for Standardization, 1994. $42 \mathrm{p}$.

INTERNATIONAL SEED TESTING ASSOCIATION. ISTA handbook on seedling evaluation. 3. ed. Switzerland: International Seed Testing Association, 2006. 128 p.

INTERNATIONAL SEED TESTING ASSOCIATION. ISTA method validation for seed testing. 1. Ed. Switzerland: International Seed Testing Association. 2007. 70 p.

KATAOKA, V. Y.; CARVALHO, M. L. M.; OLIVEIRA, M. S.; CALDEIRA, C. M. Validation of methodologies for germination test in oil radish seed (Raphanus sativus var. oleiferus). Revista Brasileira de Sementes, Londrina, v. 33, n. 1, p. 69-79, 2011. http://dx.doi.org/10.1590/S0101-31222011000100008

MANDEL, J. The validation of measurement through interlaboratory studies. Chemometrics and Intelligent Laboratory Systems, Hertfordshire, v. 11, n. 1, p. 109-119, 1991. http://dx.doi.org/10.1016/01697439(91)80058-X 
MATTHEWS, S.; WAGNER, M.H.; RATZENBOECK, A.; KHAJEH-HOSSEINI, M.; CASARINI, E.; ELKHADEM, R.; EL YAKHLIFI, M.; POWELL, A.A. Evaluation of early counts of radicle emergence during germination as a repeatable and reproducible vigour test for maize. ISTA Method Validation Reports. Basserdorf: International Seed Testing Association, n.6, p. 29-46, 2011.

NOGUEIRA, F. C. B.; MEDEIROS FILHO, S.; GALLÃO, M. I. Morphological characterization of fruits, seeds, seedlings and germination of Dalbergia cearensis Ducke - Fabaceae. Acta Botanica Brasilica, Feira de Santana, v. 24, n. 4, p. 978-985, 2010. http://dx.doi.org/10.1590/S0102-33062010000400013

NOLETO, L. G.; PEREIRA, M. F. R.; AMARAL, L. I. V. Structural and physiological changes in seeds and seedlings of Copaifera langsdorffii Desf. (Leguminosae - Caesalpinioideae) submitted to sodium hypochlorite treatment. Revista Brasileira de Sementes, Londrina, v. 32, n. 1, p. 45-52, 2010.

PEREIRA, R. S.; SANTANA, D. G.; RANAL, M. A. Seedling emergence from newly-collected and storage seeds of Copaifera langsdorffii Desf. (Caesalpinoideae), Triângulo Mineiro, Brazil. Revista Árvore, Viçosa, v. 33, n. 4, p. 643-652, 2009.

PEREZ, S. C. J. G. A.; PRADO, C. H. B. A. Efeitos de diferentes tratamentos pré-germinativos e da concentração de alumínio no processo germinativo de Sementes de Copaifera langsdorffii Desf. Revista Brasileira de Sementes, Londrina, v. 15, n. 1, p. 115-118. 1993. http://dx.doi.org/10.17801/01013122/rbs.v15n1p115-118

PINTO, S. I. C.; SOUZA, A. M.; CARVALHO, D. Genetic variability by isoenzymes in populations of Copaifera langsdorffii Desf. in two fragments of riparian forest. Scientia Forestalis, Piracicaba, n. 65, p. 4048, 2004.

POWELL, A. A. Evaluation of the controlled deterioration test as a repeatable and reproducible vigour test for Brassica species. ISTA Method Validation Reports. Basserdorf: International Seed Testing Association, n.6, p.92-123. 2009.

RESSEL, K.; GUILHERME, F. A. G.; SCHIAVINI, I.; OLIVEIRA, P. E. Functional morphology and ecology of tree species seedlings of the Ecological Station of Panga, Uberlândia, Minas Gerais. Revista Brasileira de Botânica, São Paulo, v. 27, n. 2, p. 311-323, 2004.

RIGAMONTE-AZEVEDO, O. C.; WADT, P. G. S.; WADT, L. H. O. Oil resin production potential of Copaifera spp natural populations in the southwestern Brazilian Amazon. Revista Árvore, Viçosa, v. 30, n. 4 , p. 583-591, 2006.

SOUSA, D. M. M.; BRUNO, R. L. A.; DORNELAS, C. S. M.; ALVES, E. U.; ANDRADE, A. P.; NASCIMENTO, L. C. Tamarind fruit and seed morphological characterization and post-seminal development Leguminosae: Caesalpinioideae. Revista Árvore, Viçosa, v. 34, n. 6, p. 1009-1015, 2010.

THOMPSON, K.; OOI, M. K. J. To germinate or not to germinate: more than just a question of dormancy. Seed Science Research, Cambridge, v. 20, n. 4, p. 209-211, 2010.

http://dx.doi.org/10.1017/S0960258510000267

VEIGA JÚNIOR, V. F.; ANDRADE JÚNIOR, M. A.; FERRAZ, I. D. K.; CHRISTO, H. B.; PINTO, A. C. Constituents from Copaifera officinalis L. seeds. Acta Amazonica, Manaus, v. 37, n. 1, p. 123-126, 2007. WAENY, J. C. C. Repetitividade e reprodutividade II. 1. ed. São Paulo: IPT, 1980. 14 p. 